\title{
BIBLIOTIKA : Jurnal Kajian Perpustakaan dan Informasi
}

Volume 2 Nomor 2, 2018

Journal homepage : http://journal2.um.ac.id/index.php/bibliotika

\section{Layanan Anak pada Dinas Perpustakaan Umum dan Arsip Kota Malang}

Florensia Ellena Putri Dewanthy ${ }^{*}$, Kusubakti Andajani, Dwi Novita Ernaningsih Program Studi S1 Ilmu Perpustakaan Universitas Negeri Malang

\begin{tabular}{l} 
A R T I C L E \\
I N F O \\
\hline \\
Article history: \\
Received: 20 July 2018 \\
Accepted: 23 Sept 2018 \\
Published: 15 Nov 2018 \\
Keyword: \\
perpustakaan umum, \\
layanan anak
\end{tabular}

\begin{abstract}
A B S T R A C T
Tujuan dari penelitian ini untuk mendeskripsikan penyelenggaraan kegiatan layanan anak di Dinas Perpustakaan Umum dan Arsip Kota Malang, meliputi layanan kunjung berkelompok dan layanan mandiri. Penelitian ini menggunakan pendekatan kualitatif dengan jenis penelitian deskriptif. Sumber data penelitian adalah pustakawan layanan anak dan pemustaka anak sekolah dasar serta data pendukung dari telaah dokumen. Pengumpulan data dilakukan dengan menggunakan teknik wawancara, observasi, dan dokumentasi. Kegiatan analisis dimulai dari tahap mengolah dan mempersiapkan data untuk dianalisis, membaca seluruh data, memberi kode data, tema deskripsi, penyajian data, dan interpretasi data. Berdasarkan hasil penelitian, bahwa pada layanan kunjung berkelompok pemustaka cenderung memiliki respon dan minat yang sangat baik jika dibandingkan dengan layanan mandiri minat pemustaka rendah.
\end{abstract}

\section{PENDAHULUAN}

Perkembangan dan penyelenggaraan perpustakaan sangat tergantung dengan pola kehidupan masyarakat, kebutuhan pengetahuan masyarakat dan teknologi. Adapun jenis perpustakaan, salah satunya ialah perpustakaan umum. Perpustakaan umum merupakan institusi yang menyediakan sumber belajar sesuai dengan kebutuhan masyarakat. Hal tersebut sesuai dengan pernyataan Sutarno (2006), perpustakaan umum merupakan lembaga pendidikan bagi masyarakat luas dengan menyediakan berbagai informasi, ilmu pengetahuan, teknologi dan budaya, sebagai sumber belajar untuk memperoleh dan meningkatkan ilmu pengetahuan bagi seluruh lapisan masyarakat. Sehingga perpustakaan umum memiliki fungsi dan kedudukan untuk meningkatkan pengetahuan masyarakat setempat. Di sisi lain perpustakaan umum juga memiliki beberapa layanan yang menjadi barometer keberhasilan penyelenggaraan perpustakaan, salah satunya ialah layanan anak (Safii, 2017).

Layanan anak dapat disebut sebagai upaya dari perpustakaan umum guna menjaring pembaca sebanyak-banyaknya dan sedini mungkin mengenalkan perpustakaan kepada anak-anak. Menurut Yusuf (1996), layanan anak memiliki tujuan utama, yaitu; (1) penyediaan koleksi yang

\footnotetext{
* Corresponding author.

E-mail addresses: florensiaellena15@gmail.com (Florensia Ellena Putri Dewanthy)
}

ISSN : 2579-3802 (Online) - BIBLIOTIKA : Jurnal Kajian Perpustakaan dan Informasi is licensed under Creative Commons Attribution-ShareAlike 4.0 International License (http://creativecommons.org/licenses/BY/4.0/). 
dibutuhkan serta menarik bagi anak dan masyarakat pada umumnya, (2) memberikan bimbingan kepada pengguna terkait bahan bacaan yang sesuai pada umurnya, (3) mengembangkan kegemaran sertai bertanggung jawab pada penumbuhan minat baca anak, (4) meningkatkan kecakapan anak serta memberi bantuan adaptasi sosial, (5) membentuk pribadi anak yang memiliki kepedulian dan kohesi sosial yang baik.

Dinas Perpustakaan Umum dan Arsip Kota Malang sama halnya dengan perpustakaan umum lainnya juga memiliki layanan anak. Berbagai kegiatan layanan disiapkan untuk kebutuhan anak-anak dari pemilihan bahan pustaka hingga pada pelayanan yang disesuaikan menurut usia dan selera anak. Kegiatan yang diselenggarakan pada layanan anak di Dinas Perpustakan Umum dan Arsip Kota Malang meliputi; (1) layanan kunjung berkelompok; layanan orientasi perpustakaan, layanan storytelling, layanan pemutaran film dan (2) layanan mandiri; layanan permainan edukatif, layanan pojok kreativitas. Penyelenggarakan berbagai kegiatan layanan yang baik dan sesuai dengan kebutuhan anak akan membuat anak-anak merasa nyaman berada dalam ruangan anak. Konsep penataan ruangan dijadikan sebagai dunia anak yang tidak jauh dari bermain. Dunia yang mendorong perkembangan fisik, psikologis, spiritual, sosial, emosional, kognitif, dan budaya anak-anak. Hal ini akan berpengaruh pada minat dan motivasi anak untuk berkunjung dan memanfaatkan layanan perpustakaan. Menurut Slameto (2013), menyatakan bahwa minat sebagai suatu rasa atau sikap yang memiliki kecenderungan pada sesuatu tanpa disuruh(motivasi internal). Minat pada dasarnya adalah kecenderungan akan suatu hubungan diri sendiri dengan apa yang berada di luar. Oleh karena itu kunjungan ke perpustakaan akan tinggi apabila tercipta minat dalam diri pemustaka (Safii, 2019). Ketertarikan pada perpustakaan dapat diukur dari sisi layanan, koleksi dan sarana prasarana. Rasa ketertarikan dapat dibuktikan secara kasar dengan hitungan pengunjung, semakin banyak pengunjung yang datang ini menandakan banyak pemustaka yang minat pada perpustakaan (Safii, Zen, \& Mayesti, 2018).

Pada penelitian sejenis yang berkaitan dengan minat pemustaka terhadap layanan ditulis oleh Habir (2015) dengan judul "Pengaruh Layanan Perpustakaan terhadap Minat Kunjung Pemustaka di Perpustakaan STIKES Mega Rezky Makasar". Hasil penelitian tersebut menunjukkan bahwa penyelenggaraan layanan perpustakaan berpengaruh kuat terahadap minat kunjung pemustaka. Perbedaan penelitian yang penulis teliti ialah mengenai penyelenggaraan kegiatan layanan anak dengan minat atau motivasi pemustaka dalam memanfaatkan layanan anak, serta perbedaan penelitian pada metode dan jenis penelitian yang digunakan. Tujuan penelitian ini adalah untuk mendeskripsikan penyelenggaraan kegiatan layanan anak di Dinas Perpustakaan Umum dan Arsip Kota Malang, meliputi layanan kunjung berkelompok dan layanan mandiri.

\section{METODE PENELITIAN}

Penelitian ini menggunakan pendekatan kualitatif dengan jenis penelitian deskriptif. Sumber data penelitian ini adalah pustakawan layanan anak dan pemustaka anak sekolah dasar serta data pendukung dari telaah dokumen, yakni buku profil perpustakaan dan data statistik pemustaka. Pengumpulan data dilakukan dengan menggunakan teknik wawancara, observasi dan dokumentasi. Instrumen yang digunakan untuk mengumpulkan data yaitu menggunakan wawancara terstruktur.

Teknik analisis data yang digunakan dalam penelitian ini mencakup enam analisis. Pertama, mengolah dan mempersiapkan data untuk dianalisis. Data tersebut kemudian dipilah dan dikategorikan sesuai dengan fokus penelitian, yakni layanan kunjung berkelompok dan layanan mandiri. Kedua, membaca seluruh data. Hal ini dilakukan untuk memaknai informasi dan data yang didapatkan dari narasumber secara keseluruhan. Ketiga, memberi kode data yang bertujuan mempermudah peneliti dalam melakukan analisis data yang didapat. Kode yang digunakan adalah kombinasi kode huruf dan angka. Kode huruf menyatakan kode informan dan kode angka menyatakan jawaban informan dari pertanyaan yang keberapa. Keempat, tema deskripsi. Peneliti mengelompokkan informasi-informasi atau data-data tersebut ke dalam tema-tema berdasarkan topik yang sama. Selanjutnya, data tersebut dideskripsikan sesuai dengan hasil yang diperoleh. 
Kelima, penyajian data. Data hasil yang disajikan berdasarkan temuan-temuan di lapangan yang diperoleh dari hasil wawancara, observasi, dan telaah dokumen. Keenam, interpretasi data. Peneliti membandingkan hasil penelitian terdahulu dan membahasnya dengan teori-teori yang terkait.

\section{HASIL PENELITIAN}

Dinas Perpustakaan Umum dan Arsip Kota Malang menyediakan kegiatan layanan anak, yakni (1) layanan kunjung berkelompok meliputi kegiatan; layanan orientasi perpustakaan, layanan storytelling, dan layanan pemutaran film, (2) layanan mandiri meliputi kegiatan; layanan permainan edukatif, dan layanan pojok kreativitas

\section{Layanan Kunjung Berkelompok}

Kegiatan pertama pada layanan kunjung berkelompok, yaitu layanan orientasi perpustakaan. Layanan orientasi perpustakaan mengenalkan secara langsung kepada pemustaka mengenai bagaimana cara menjadi anggota perpustakaan, apa saja fasilitas perpustakaan, apa saja fungsi setiap ruang layanan perpustakaan, hingga peraturan yang ada pada layanan anak atau ruang baca anak. Pemustaka sangat antusias menjawab pertanyaan-pertanyaan pustakawan terkait tentang perpustakaan. Orientasi perpustakaan tidak hanya mengenalkan pada layanan anak namun juga mengenalkan pemustaka pada setiap layanan yang ada, seperti layanan umum dan layanan braille. Layanan orientasi memberikan banyak edukasi dan bertujuan mendekatkan anak pada perpustakaan.

Kegiatan layanan kunjung berkelompok kedua, yaitu layanan storytelling. Penyelenggaraan layanan storytelling adalah sebagai media hiburan bagi anak dengan mendongengkan cerita yang dapat menarik perhatian anak. Pemilihan cerita yang digunakan untuk mendongeng ialah cerita yang isinya mengandung pesan moral dan nasehat, guna menanamkan kebaikan bagi anak sejak dini. Teknik storytelling yang digunakan ialah dengan menggunakan media dan tanpa media. Penggunaan media maksudnya ialah mendongeng dengan menggunakan boneka atau alat musik sebagai media, sedangkan tanpa media ialah mendongeng yang dilakukan secara spontan tanpa menggunakan media penunjang apapun.

Kegiatan layanan kunjung berkelompok ketiga, yaitu layanan pemutaran film. Penyelenggaran layanan pemutaran film sebagai hiburan dan pembelajaran melalui media audiovisual. Film yang ditayangkan merupakan film kartun anak yang mengandung unsur pendidikan, guna mengembangkan imajinasi anak. Pemustaka anak sangat antusias mengikuti layanan pemutaran film, pemustaka juga dapat menceritakan kembali alur cerita dari film yang ditayangkan tersebut.

\section{Layanan Mandiri}

Layanan permainanan edukatif bermanfaat untuk pengendalian dan pengembangan motorik anak. Permainan edukatif yang tersedia, yakni permainan untuk motorik kasar dan permainan untuk motorik halus. Permainan motorik kasar seperti ayunan, prosotan, dan jungkatjungkit. Sedangkan permainan untuk motorik halus seperti balok susun, puz:le, donat susun warna, basic maze, dan pasak kombinasi. Pembelajaran melalui permainan edukatif secara langsung dapat melatih logika dan daya kreativitas anak. Namun, pemustaka anak tidak antusias dan jarang memanfaatkan permainan sebagai media pembelajaran. Kondisi permainan yang tersedia banyak mengalami kerusakan dan permainan terkesan membosankan. Kerusakan permainan disebabkan oleh kurangnya pengawasan dari pustakawan, hal tersebut dikarenakan pustawakan terlalu pasif saat anak-anak menggunakan permainan edukatif tersebut. Selain itu keterbatasan anggaran juga berakibat pada layanan ini, karena tidak dapat untuk memperbaharui koleksi permainan.

Lain halnya layanan pojok kreativitas yang bertujuan untuk melatih anak agar bebas berkreasi, mengembangkan daya kreativitas dan imajinasinya. Pojok kreativitas merupakan istilah yang dibuat oleh perpustakaan, dikarenakan letak layanan yang berada tepat pada pojok ruang baca anak maka dari itu dinamakan dengan layanan pojok kreativitas. Fasilitas yang disediakan pada layanan ini ialah berupa alat gambar, kertas lipat dan plastisin. Respon pemustaka anak terhadap layanan ini cukup baik, antusias pemustaka dalam memanfaatkan layanan pojok 
kreativitas Fasilitias yang telah digunakan seperti gambar, keterampilan dan plastisin yang dibuat oleh pemustaka dapat dibawa pulang. Namun, minat dan ketertarikan pemustaka anak cukup rendah terhadap layanan pojok kreativitas. Terdapat beberapa hambatan yakni kondisi layanan pojok kreativitas Dinas Perpustakaan Umum dan Kota Malang kurang mendapat perhatian, dikarenakan keterbatasan anggaran sehingga tidak dapat memperbaharui dan menambahkan koleksi atau fasilitas layanan. Hal tersebut juga disebabkan kurangnya keaktifan dari pihak pustakawan untuk melakukan promosi kepada pemustaka mengenai layanan pojok kreativitas yang tersedia pada ruang baca anak.

\section{PEMBAHASAN}

\section{Kajian Layanan Kunjung Berkelompok}

Penyelenggaraan layanan kunjung berkelompok pada layanan anak Dinas Perpustakaan Umum dan Arsip Kota Malang sangat mempertimbangkan kebutuhan pemustaka, khususnya anak-anak mulai dari tingkat TK hingga tingkat SD. Layanan kunjung berkelompok dapat menjadi perantara pembelajaran nonformal dan menunjang anak menjadi pembelajar yang mandiri melalui perpustakaan. Kegiatan layanan yang tersedia pada kunjung berkelompok meliputi layanan orientasi perpustakaan, layanan storytelling, dan layanan pemutaran film.

Layanan orientasi perpustakaan merupakan layanan yang diselenggarakan dengan tujuan untuk mengenalkan kepada anak-anak mengenai arti dan manfaat perpustakaan, mengenalkan prosedur menjadi anggota perpustakaan, prosedur cara meminjam buku, mengenalkan ruangan, koleksi, serta peraturan perpustakaan. Istilah orientasi perpustakaan sama halnya dengan bimbingan pemakai, menurut pendapat Sutarno (2003:102) bimbingan pemakai merupakan kegiatan menuntun, mengarahkan, serta memberikan penjelasan tentang tata cara menelusur sumber informasi melalui Online Public Access Catalog (OPAC) dan perangkat lainnya.

Penyelenggaraan orientasi perpustakaan agar berjalan dengan baik, maka perlu menentukan terlebih dahulu metode yang sesuai dan efektif untuk digunakan, menurut pendapat Irawan (2005:21) metode orientasi perpustakaan terbagi menjadi dua, yaitu

(1) metode langsung, yaitu pengenalan perpustakaan yang diberikan melalui hubungan langsung antara pustakawan dengan pemustaka. Metode langsung terdiri dari dua teknik, yakni; lectures atau ceramah, isi ceramah mengajarkan pemakai bagaimana cara menggunakan perpustakaan dengan baik dalam rangka mengatasi kebutuhan-kebutuhan akan informasi, dan the tour of the library atau wisata perpustakaan, kegiatan yang dilakukan adalah melakukan perjalanan keliling di perpustakaan sekaligus memperkenalkan perpustakaan secara umum, (2) metode tidak langsung, yaitu pengenalan perpustakaan melalui media tertentu. Metode tidak langsung terdiri dari dua teknik, yakni; audio visual, pengenalan perpustakaan melalui media kaset, televisi, slide, dan teknik printed guides atau buku pedoman dan pamflet, yang merupakan pemberian keterangan mengenai layanan perpustakaan melalui buku pedoman.

Sehubungan dengan pendapat Irawan (2005:21), Dinas Perpustakaan Umum dan Arsip Kota Malang menggunakan metode orientasi perpustakaan secara langsung dengan teknik lectures (ceramah) dan the tour of the library (wisata perpustakaan). Teknik orientasi perpustakaan lectures atau ceramah dilakukan oleh pustakawan secara spontan, pustakawan menjelaskan tentang gambaran umum perpustakaan serta mengarahkan kepada pemustaka anak mengenai prosedur dan aturan menjadi anggota perpustakaan. Sedangkan teknik orientasi kedua the tour of the library atau wisata perpustakaan, rombongan pemustaka anak sekolah dasar dibimbing oleh pustakawan untuk berkeliling perpustakaan. Pemustaka diberikan pengetahuan baru mengenai layanan lainnya, seperti layanan umum, layanan khusus atau disebut layanan braille yang ditujukan khusus untuk pemustaka tuna netra (Safii dkk., 2018). Penyelenggaraan layanan orientasi perpustakaan tidak dilakukan secara perseorangan tetapi dilakukan secara kelompok, hal tersebut dimaksudkan untuk menghemat waktu dan tenaga.

Kegiatan kedua layanan kunjung berkelompok adalah layanan storytelling, merupakan bentuk komunikasi antara pencerita dengan sejumlah peserta melalui suara dan gerakan (Lasa, 
2007:190). Tujuan penyelenggaraan layanan storytelling agar anak-anak terpacu niatnya untuk membaca buku dan layanan storytelling sebagai media hiburan. Terdapat dua teknik dalam bercerita, selaras dengan pendapat Rahayu (2013:88) bahwa penerapan kegiatan bercerita atau storytelling dapat dilakukan dalam dua teknik, yaitu kegiatan bercerita dengan media alat peraga adalah kegiatan bercerita yang dalam pelaksanaannya menggunakan alat peraga langsung maupun tidak langsung seperti boneka, gambar, papan, flannel, buku, alat musik atau benda-benda lainnya. Sedangkan teknik kedua adalah kegiatan bercerita tanpa alat peraga, merupakan kemampuan verbal yang dilakukan secara spontan atau langsung. Dinas Perpustakaan Umum dan Arsip Kota Malang menggunakan teknik pertama yakni bercerita menggunakan alat peraga, media yang digunakan adalah boneka atau menggunakan buku cerita. Antusias pemustaka anak terhadap layanan storytelling cukup baik, namun kegiatan storytelling tidak menjadi kegiatan rutin saat kunjung berkelompok berlangsung. Hal tersebut dikarenakan keterbatasan waktu dan keterbatasan SDM untuk menjadi pendongeng (Habsari, 2017).

Lebih lanjut kegiatan layanan kunjung berkelompok yang ketiga ialah layanan pemutaran film yang merupakan salah satu bentuk media pembelajaran bagi anak-anak di lingkungan non formal. Media pembelajaran diartikan Kustiawan (2016:6) sebagai sesuatu yang digunakan untuk menyalurkan pesan atau bahan pembelajaran sehingga dapat merangsang perhatian, minat, pikiran, dan perasaan siswa dalam kegiatan belajar untuk mencapai tujuan pembelajaran tertentu. Media pembelajaran berfungsi sebagai alat bantu yang dapat mempermudah proses penerimaan materi pelajaran yang disampaikan. Menurut jenis media audio, film atau video termasuk ke dalam media VCD dan DVD yang merupakan bahan pembelajaran tampak dengar (audio visual) yang dapat digunakan untuk menyampaikan pesan-pesan atau materi pembelajaran (Noor, 2018).

Pembelajaran menggunakan media audio visual sangat tepat digunakan untuk anak-anak, karena umumnya anak-anak usia TK atau SD cenderung cepat bosan dalam hal pelajaran maka dengan adanya media pembelajaran tersebut anak-anak menjadi tertarik, tidak mudah merasa bosan dan sebagai alternatif dalam meningkatkan motivasi belajar anak (Pancarrani, Amroh, \& Noorfitriana, 2018). Tujuan dan manfaat dari layanan pemutaran film ialah untuk memfasilitasi anak agar dapat terpacu niatnya untuk datang ke perpustakaan serta mengembangkan imajinasi anak melalui film, selain itu layanan ini bermanfaat sebagai media hiburan bagi anak. Layanan pemutaran film Dinas Perpustakaan Umum dan Arsip Kota Malang cukup baik, pemustaka menikmati kegiatan layanan tersebut dengan antusias. Film yang ditayangkan yang mengandung unsur pendidikan, namun koleksi film sangat terbatas dikarenakan keterbatasan anggaran (Safii, 2017).

Penyelenggaraan layanan kunjung berkelompok di layanan anak Dinas Perpustakaan Umum dan Arsip Kota Malang menunjukan manfaat positif bagi pengguna atau pemustaka anak, hal tersebut terbukti bahwa: (1) pemustaka memiliki pengetahuan baru tentang perpustakaan, (2) pemustaka menjadi memahami cara memanfaatkan perpustakaan dan mengetahui fungsi perpustakaan, (3) pemustaka menjadi paham akan koleksi dan peraturan yang ada di perpustakaan, (4) memberikan pendidikan nonformal melalui media hiburan, yakni storytelling dan film, (5) membiasakan pemustaka untuk berinteraksi terhadap sesama dengan belajar secara berkelompok. Tersedianya layanan kunjung berkelompok juga diharapkan dapat menanamkan minat pemustaka agar memiliki ketertarikan terhadap perpustakaan, hingga nantinya menjadi suatu kebiasaan berkunjung. Oleh karena itu, anak-anak mulai dini harus dibiasakan untuk memanfaatkan layanan kunjung berkompok. Sejalan dengan pernyataan Natadjumena (2005:3) "apabila telah menjadi kebiasaan dan setelah menjadi suatu kebutuhan maka minat kunjung bisa menjadi budaya kehidupan".

\section{Kajian Layanan Mandiri}

Penyelenggaraan layanan mandiri di Dinas Perpustakaan Umum dan Arsip Kota Malang bertujuan untuk mengembangkan motorik dan kreativitas anak, meliputi layanan permaianan edukatif dan layanan pojok kreativitas. Layanan permainanan edukatif bermanfaat untuk 
pengendalian dan pengembangan motorik anak. Hal tersebut selaras dengan pendapat Kustiawan (2016:191), bahwa manfaat permainan, yaitu membantu perkembangan sosial, membantu perkembangan emosional, membantu perkembangan berbahasa anak, membantu perkembangan kognitif anak, membantu perkembangan fisik motorik anak, membantu perkembangan bidang seni anak, dan membantu mempertajam keindraan (Safii, 2017). Kustiawan (2016:196) juga menyatakan bahwa terdapat macam-macam alat permainan edukatif, seperti; jenis-jenis boneka, balok bangunan, balok ukur polos, menara gelang, puzel, papan pengenalan warna, papan pengenalan bentuk, papan pengenalan angka, krincingan bayi, gantungan bayi, dan lain-lain. Hal tersebut sesuai dengan permainan yang disediakan oleh Dinas Perpustakaan Umum dan Arsip Kota Malang, yakni permainan untuk motorik kasar dan permainan untuk motorik halus. Permainan motorik kasar seperti ayunan, prosotan, dan jungkat-jungkit. Sedangkan permainan untuk motorik halus seperti balok susun, puzzle, donat susun warna, basic maze, dan pasak kombinasi (Jayapada, Faisol, \& Kiptiyah, 2018).

Namun penyelenggaraan layanan permainan edukatif pada layanan anak Dinas Perpustakaan Umum dan Arsip Kota Malang tidak berjalan dengan maksimal, hal tersebut terbukti bahwa: (1) pemustaka bosan dengan permainan yang tersedia, karena permainan banyak yang mengalami kerusakan, (2) lingkungan bermain yang kurang mendukung untuk pemustaka, (3) keterbatasan anggaran dana dari perpustakaan sehingga mainan tidak dapat diperbaharui. Hal tersebut akan berpengaruh pada minat pemustaka, selaras dengan pernyataan Fadlillah (2013:158) "lingkungan yang kurang mendukung akan dapat mempengaruhi anak dalam bermain, lingkungan yang sepi dari anak-anak akan kurang rasa bermainnya dibandingkan dengan lingkungan yang terdapat banyak anak-anak".

Layanan mandiri kedua ialah pojok kreativitas, merupakan layanan yang disediakan oleh Dinas Perpustakaan Umum dan Arsip Kota Malang bertujuan untuk mengembangkan kreativitas dan imajinasi anak. Sebagaimana Fadlillah (2013:194) berpendapat, bahwa pengertian dari kreatif adalah berpikir dan melakukan sesuatu untuk menghasilkan cara atau hasil baru dari sesuatu yang telah dimiliki. Melatih kreativitas anak dapat dilakukan dengan memberikan kebebasan kepada anak untuk berekspresi sesuai dengan keinginannya (Pancarrani dkk., 2018). Lain halnya Shahib (2010:42) menyatakan bahwa kreativitas merupakan salah satu kemampuan manusia untuk mengintegrasikan stimulus luar dengan memori yang telah dimiliki sebelumnya menjadi suatu bentuk baru.

Fasilitas yang disediakan pada layanan ini ialah berupa alat gambar, kertas lipat dan plastisin. Respon dan antusias pemustaka anak cukup baik dalam memanfaatkan layanan pojok kreativitas. Fasilitias yang telah digunakan seperti gambar, keterampilan dan plastisin yang dibuat oleh pemustaka dapat dibawa pulang. Layanan pojok kreativitas memberi dampak positif bagi pemustaka, terbukti bahwa: (1) pemustaka mampu berimajinasi dalam membuat suatu karya, (2) pemustaka menjadi mandiri dalam mengembangkan kreativitasnya, (3) pemustaka dapat mengekspresikan emosi melalui gambar. Oleh karena itu layanan ini diselenggarakan agar dapat menarik minat pemustaka melalui fasilitas yang disediakan, karena pada dasarnya kreativitas tidak dapat muncul secara spontan tanpa adanya media atau perantara untuk menyalurkannya (Safii, 2019). Hal tersebut sesuai dengan pernyataan Shahib (2010:42) "kreativitas bukan hasil dadakan, tetapi merupakan hasil bersama dari logika, daya cipta, fisik, motivasi, perasaan dan imajinasi yang terintegrasi menjadi ide baru yang kemudian ide tersebut dapat diimplementasikan dalam bentuk karya atau dalam bentuk dunia pendidikan sebagai karya ilmiah".

\section{PENUTUP}

\section{Simpulan}

Dinas Perpustakaan Umum dan Arsip Kota Malang menyelenggarakan layanan anak yang berguna untuk membina, mengembangkan kecapakan anak dan sebagai sarana pembelajaran non formal. Layanan anak yang tersedia meliputi dua layanan, yakni (1) layanan kunjung berkelompok meliputi kegiatan; orientasi perpustakaan, storytelling, dan pemutaran film, (2) layanan 
mandiri meliputi kegiatan; layanan permainan edukatif dan layanan pojok kreativitas. Layanan kunjung berkelompok dapat menunjang anak menjadi pembelajar yang mandiri melalui perpustakaan. Pengenalan dan pendekatan perpustakaan melalui kegiatan orientasi perpustakaan menjadi ikon utama dalam penyelenggaraan layanan kunjung berkelompok tersebut. Kegiatan storytelling dan pemutaran film juga dilayankan untuk memfasilitasi pemustaka anak agar semakin tertarik terhadap perpustakaan serta menjadi media hiburan dalam pembelajaran nonformal. Sebagaimana layanan mandiri yang diselenggarakan perpustakaan, seperti permainan edukatif dan layanan pojok kreativitas merupakan layanan yang berguna untuk melatih motorik dan mengembangkan kreativitas anak. Penyelenggaraan layanan tersebut dilengkapi dengan fasilitasfasilitas yang menunjang. Pada layanan permainan edukatif disediakan permainan-permainan untuk mengasah motorik halus dan motorik kasar anak, sedangkan pada layanan pojok kreativitas disediakan alat-alat untuk menyalurkan kreativitas anak.

\section{Saran}

Saran yang dapat penulis sampaikan berdasarkan simpulan diatas yaitu terkait layanan kunjung berkelompok. Pada layanan storytelling, hendaknya menambahkan tenaga kerja dan membuat jadwal secara rutin, agar layanan storytelling dapat terlayankan sesuai dengan tujuan yang akan dicapai. Selain itu pada layanan pemutaran film, hendaknya melakukan pengadaan koleksi film setiap tahunnya, agar koleksi film pada layanan pemutaran film tidak monoton dan pemustaka anak tidak merasa bosan. Mengenai keterbatasan anggaran dana, pihak Dinas Perpustakaan Umum dan Arsip Kota Malang dapat meningkatkan jalinan kerjasama dengan pihak yang dapat menunjang kebutuhan layanan anak. Terkait layanan mandiri, pada layanan permainan edukatif hendaknya pustakawan lebih memperhatikan kelayakan kondisi permainan dan melakukan perawatan terhadap koleksi permainan agar tidak mengalami kerusakan. Pada layanan pojok kreativitas, hendaknya pustakawan lebih menekankan pada promosi keberadaan layanan tersebut sehingga pemustaka anak mengetahui tentang adanya layanan pojok kreativitas dan dapat menggunakan fasilitas-fasilitas yang telah disediakan.

\section{DAFTAR PUSTAKA}

Fadlillah, M. (2013). Pendidikan Karakter Anak Usia Dini. Joogjakarta: Ar-Ruzz Media.

Habir. (2015). Pengaruh Layanan Perpustakaan terhadap Minat Kunjung Pemustaka di Perpustakaan STIKES Mega Rezky Makasar. Khizanah AL Hikmah. Jurnal Ilmu Perpustakaan, Informasi, dan Kearsipan, (Online), vol.3 (2), hlm. 1-10, (http://id.portalgaruda.org/).

Habsari, Z. (2017). DONGENG SEBAGAI PEMBENTUK KARAKTER ANAK. BIBLIOTIKA: Jurnal Kajian Perpustakaan Dan Informasi, 1(1), 21-29. https://doi.org/10.17977/um008v1i12017p021

Irawan, S. (2005). Pentingnya Pendidikan Pemakai bagi Mahasiswa dalam Penelusuran Informasi melalui Catalog Online (OPAC): Studi Kasus pada perpustakaan UIN Syarf Hudayatullah. Jakarta. Fakultas Adab dan Humaniora. Universitas Islam Negeri Jakarta

Jayapada, G., Faisol, F., \& Kiptiyah, B. M. (2018). KEARIFAN LOKAL DALAM CERITA RAKYAT SEBAGAI MEDIA PENDIDIKAN KARAKTER UNTUK MEMBENTUK LITERASI MORAL SISWA. BIBLIOTIKA : Jurnal Kajian Perpustakaan dan Informasi, 1(2), 60-62.

Kustiawan, U. (2016). Pengembangan Media Pembelajaran Anak Usia Dini. Malang: Gunung Samudera

Lasa, Hs. (2007). Manajemen Perpustakaan Sekolah. Yogyakarta: Pinus Book Publisher

Natadjumena, R. (2005). Masyarakat dan Minat Baca. Dalam Media Pustakawan, vol.12. No. 2, Juni 2005 
Noor, M. U. (2018). Penilaian kualitas informasi sebagai bentuk sikap tabayyun ketika menerima informasi di sosial media dan internet. BIBLIOTIKA: Jurnal Kajian Perpustakaan dan Informasi, 2(1), 33-40.

Pancarrani, B., Amroh, I. W., \& Noorfitriana, Y. (2018). PERAN LITERASI ORANG TUA DALAM PERKEMBANGAN ANAK. BIBLIOTIKA: Jurnal Kajian Perpustakaan dan Informasi, 1(2), 23-27.

Rahayu, A. Y. (2013). Anak Usia TK: Menumbubkan Kepercayaan Diri melalui Kegiatan Membaca. Jakarta: Indeks

Safii, M. (2017). Perencanaan Perpustakaan Universitas Mercu Buana(UMB) Cabang Cibubur. JIPI (Jurnal Ilmu Perpustakaan dan Informasi), 2(1), 115-128. https://doi.org/10.30829/jipi.v2i1.925

Safii, M. (2019, Februari). Redefining The Five Laws of Library Science in the Digital Age. Dipresentasikan pada 2nd Internasional Conference on Culture and Language in Southeast Asia (ICCLAS 2018). https://doi.org/10.2991/icclas-18.2019.7

Safii, M., Zen, Z., \& Mayesti, N. (2018). Strategi Perpustakaan Perguruan Tinggi dalam Menerapkan Library 2.0. JIPI (Jurnal Ilmu Perpustakaan dan Informasi), 3(1), 144-159. https://doi.org/10.30829/jipi.v3i1.1660

Shahib, N. (2010). Pembinaan Kreativitas Anak Guna Membangun Kompetensi. Bandung. PT. Alumni Slameto. (2003). Belajar dan Faktor-Faktor yang Mempengarubi. Jakarta: Rineka Cipta

Sutarno, NS. (2006). Perpustakaan dan Masyarakat. Jakarta: CV. Sagung Seto

Sutarno, NS. (2003). Perpustakaan dan Masyarakat. Jakarta: Yayasan Obor Indonesia

Yusuf, T. (1996). Materi Pokok Manajemen Perpustakaan Umum: PUST2244/3 SKS. Jakarta: Universitas Terbuka. 